\title{
A Study on Impact of CSR Activities on Factors that Contribute in Influencing Company's Brand Equity
}

\author{
Pranjal Page \\ SVKM's NMIMS (Deemed to be University), West Mumbai, Maharashtra, India.
}

CITATION: Page, Pranjal (2020), "A Study on Impact of CSR Activities on Factors that Contribute in Influencing Company's Brand Equity", MERC Global's International Journal of Management, Vol. 8, Issue 3, pp. 94-102.

ARTICLE HISTORY: Submitted: March 27, 2020, Revision received: April 27, 2020, Accepted: May 15, 2020

ARTICLE TYPE: Research paper

\begin{abstract}
This paper describes the factors that contribute to the impact of corporate social responsibility (CSR) activities on a company's Brand Equity. CSR activities have now become one of the major approaches for companies to build corporate reputation, brand image, brand awareness which results in the development of brand performance. In recent times, major companies have started the use of green marketing as a tool in their branding strategies. The study shows various factors that together in a synchronized way result in influencing brand equity and how companies can use these approaches to build influence in the market.
\end{abstract}

KEYWORDS: Corporate social responsibility, Brand equity, Corporate reputation, Consumer perception, Green marketing, Brand awareness.

\section{BIBLIOGRAPHY}

1. Bharathi, G. and Teki, S. (2018), "CSR Spending Analysis of Select BSE Listed Companies in the Light of the new Companies Act, 2013", MERC Global's International Journal of Management, Vol. 6, Issue 4, pp. 141-148.

2. Da-Chang, Pai; Chi-Shiun, Lai; Chih-Jen, Chiu and Chin-Fang, Yang (2015), "Corporate Social Responsibility and Brand Advocacy in Business-to-Business Market: The Mediated Moderating Effect of Attribution", Journal of Business Ethics, Vol. 126, Issue 4, pp. 685-696.

3. Kaur, Manmeet and Singh, Rajpal (2016), "Corporate Social Responsibility: A Step towards Fashion or Future?”, MERC Global's International Journal of Management, Vol. 4, Issue 1, pp. 01-05.

4. Khan, M. I. (2015), "Building company reputation and brand equity through CSR: the mediating role of trust", International Journal of Bank Marketing, Vol. 33, Issue 6, pp. 840-856.

5. Niazi, M. S.; Haider, M. I.; Islam, T. and Rehman, S. U. (2012), "The Impact of Corporate Social Responsibility on Brand Equity", European Journal of Social Sciences, Vol. 34, Issue 3, pp. 520-529.

6. Raman, M.; Lim, W. and Nair, S. (2012), "The impact of corporate social responsibility on consumer loyalty", Kajian Malaysia, Vol. 30, Issue 2, pp. 71-93.

7. Rodrígueza, P. G.; Valiñob, P. C. and Burguetea, J. V. (2017), "The effects of corporate social responsibility on customer-based brand equity: Spanish hypermarket case", Economic Research, Vol. 30, Issue 1, pp. 290-301.

8. Singh, A. and Verma, P. (2017), "How CSR Affects Brand Equity of Indian Firms?", Global Business Review, Vol. 18, Issue 1, pp. 19-25.

9. Torres, Anna; H. A., Tammo; Bijmolt, Josep A. and Tribó, Peter Verhoef (2010), "Generating Global Brand Equity through Corporate Social Responsibility to Key Stakeholders", Working Papers Business Economic Series WP. 